\title{
Nocardioides pyridinolyticus sp. nov., a Pyridine-Degrading Bacterium Isolated from the Oxic Zone of an Oil Shale Column
}

\author{
JUNG-HOON YOON, ${ }^{1,2}$ SUNG-KEUN RHEE, ${ }^{2}$ JUNG-SOOK LEE, ${ }^{1}$ YONG-HA PARK, ${ }^{1}$ \\ AND SUNG TAIK LEE ${ }^{2 *}$ \\ Korean Collection for Type Cultures, Korea Research Institute of Bioscience \& Biotechnology, Yusong, \\ Taejon 305-600, ${ }^{1}$ and Department of Biological Sciences, Korea Advanced Institute of Science and Technology, \\ Taejon $305-701,^{2}$ Korea
}

\begin{abstract}
A bacterial strain which is able to degrade pyridine was previously isolated from the oxic zone of an oil shale column and described as Pimelobacter sp. strain $\mathrm{OS4}^{\mathrm{T}}$. However, Pimelobacter species have been transferred to the genera Nocardioides and Terrabacter. Strain $\mathrm{OS4}^{\mathrm{T}}$ was identified as a member of the genus Nocardioides on the basis of chemotaxonomic analysis and phylogenetic inference based on 16S ribosomal DNA (rDNA) sequence analysis. The $\mathrm{G}+\mathrm{C}$ content of strain $\mathrm{OS4}^{\mathrm{T}}$ is $72.5 \mathrm{~mol} \%$. The cell wall peptidoglycan contains LL-diaminopimelic acid as the diamino acid. The predominant menaquinone is MK-8 $\left(\mathrm{H}_{4}\right)$. The cellular fatty acid profile of strain $0 S 4^{\mathrm{T}}$ is similar to that of the genus Nocardioides. The 16S rDNA similarity of strain $\mathrm{OS4}^{\mathrm{T}}$ with previously described Nocardioides species is $94.5 \% \pm 0.7 \%$, and a phylogenetic tree based on 16S rDNA sequences revealed a distinct lineage for strain $\mathrm{OS}^{\mathrm{T}}$ within the evolutionary radiation enclosed by the genus Nocardioides. Therefore, on the basis of our data, we propose that strain $\mathrm{OS}^{\mathrm{T}}$ should be placed in the genus Nocardioides as a member of a new species, Nocardioides pyridinolyticus. The type strain of the new species is strain OS4 (= KCTC 0074BP).
\end{abstract}

Pyridine is a toxic aromatic compound which poses serious problems for human health (5). A slight modification of ring substituents can dramatically increase the toxic activity of pyridine. Pyridine occurs in the environment as a result of industrial activities $(17,23)$ and, due to its high solubility in water, is thought to be highly mobile through the environment (9). A bacterial strain which is able to degrade pyridine was recently isolated from the oxic zone of an oil shale leachate column and was identified as Pimelobacter sp. $(8,15)$.

Although the genus Pimelobacter was proposed in 1983 by Suzuki and Komagata for Arthrobacter species containing LLdiaminopimelic acid in the peptidoglycan (24), species of the genus Pimelobacter have been transferred to the genus Nocardioides or the genus Terrabacter $(3,12)$. Three Pimelobacter species, namely, Pimelobacter jensenii, Pimelobacter simplex, and Pimelobacter tumescens, were recognized first. However, O'Donnell et al. proposed that Arthrobacter simplex should be assigned to the genus Nocardioides as Nocardioides simplex (12). P. jensenii was transferred to the genus Nocardioides as Nocardioides jensenii, and $P$. tumescens was reclassified in the new genus Terrabacter as Terrabacter tumescens by Collins et al. (3).

The genus Nocardioides was introduced with its type species, Nocardioides albus, in 1976 by Prauser (13) for gram-positive, non-acid-fast, aerobic, mesophilic nocardioform actinomycetes that form a mycelium which breaks up into irregular rod- to coccuslike fragments. The members of the genus characteristically contain LL-2,6-diaminopimelic acid in their cell walls (wall chemotype I) and lack mycolic acids. They have a complex cellular fatty acid profile containing iso-, anteiso-, straightchain, unsaturated, and 10-methyl-branched acids. The major fatty acid characterizing the genus is iso- $C_{16: 0}(10,12)$. The predominant isoprenoid quinone found in the genus Nocardio-

* Corresponding author. Mailing address: Department of Biological Sciences, Korea Advanced Institute of Science and Technology, 373-1 Kusong-dong, Yusong-gu, Taejon 305-701, Korea. Phone: 82-42-8692617. Fax: 82-42-869-5617. E-mail: stlee@sorak.kaist.re.kr. ides is a tetrahydrogenated menaquinone with eight isoprene units $\left[\mathrm{MK}-8\left(\mathrm{H}_{4}\right)\right](12,27)$. There are currently five validly described Nocardioides species, namely, N. albus (13), N. jensenii (3), Nocardioides luteus (14), Nocardioides plantarum (4), and N. simplex (12). Nocardioides fastidiosa was created in 1989 by Collins and Stackebrandt (2) but was transferred to the genus Aeromicrobium (10) as Aeromicrobium fastidiosum in 1994 by Tamura and Yokota (27).

The aim of this study was to determine the exact taxonomic position of a bacterial strain previously described as Pimelobacter sp. strain OS4 $4^{\mathrm{T}}(8,15)$ that is capable of degrading pyridine. We describe morphological, physiological, and biochemical characteristics of this organism and its phylogenetic position on the basis of its $16 \mathrm{~S}$ ribosomal DNA (rDNA) sequence. On the basis of data described below, we propose that this organism should be placed in the genus Nocardioides as a new species, Nocardioides pyridinolyticus.

\section{MATERIALS AND METHODS}

Bacterial strains and culture conditions. The isolation of strain $0 S 4^{T}$ was described in a previous study (8). Strain OS4 $4^{\mathrm{T}}$ was cultivated on nutrient agar (Difco) and minimal salts medium supplemented with $0.05 \%$ (wt/vol) yeast extract and $0.05 \%$ (wt/vol) tryptone. The minimal salts medium contained (per liter) $1.0 \mathrm{~g}$ of $\mathrm{KH}_{2} \mathrm{PO}_{4}, 0.25 \mathrm{~g}$ of $\mathrm{KCl}, 0.25 \mathrm{~g}$ of $\mathrm{MgSO}_{4} \cdot 7 \mathrm{H}_{2} \mathrm{O}, 1 \mathrm{ml}$ of trace element solution (8), and $15 \mathrm{~g}$ of agar (if needed). Strain OS4 ${ }^{\mathrm{T}}$ and some reference strains were also grown at $30^{\circ} \mathrm{C}$ for 4 days on nutrient agar (Difco) for fatty acid methyl ester analysis. The following reference strains were used: $N$. albus KCTC $9186^{\mathrm{T}}$, N. jensenii KCTC $9134^{\mathrm{T}}$, N. luteus $\mathrm{KCTC} 9575^{\mathrm{T}}$, N. simplex KCTC $9106^{\mathrm{T}}$, Aeromicrobium erythreum NRRL B-3381 ${ }^{\mathrm{T}}$, Aeromicrobium fastidiosum KCTC $9576^{\mathrm{T}}$, and T. tumescens KCTC $9133^{\mathrm{T}}$.

Morphological and physiological tests. The morphology of cells grown on minimal salts medium supplemented with $0.05 \%$ (wt $/ \mathrm{vol}$ ) yeast extract and $0.05 \%$ (wt/vol) tryptone was examined by phase-contrast microscopy. Motility was determined with an optical microscope by using the hanging drop technique (18). Flagellum type was examined with transmission electron microscopy by using cells from the late exponential phase of growth. The cells were negatively stained with $1 \%$ ammonium molybdate, and after air drying the grids were examined by using a model H-800 transmission electron microscope (Hitachi, Tokyo, Japan).

Catalase activity was determined by bubble production in a $3 \%$ hydrogen peroxide solution. Oxidase activity was determined by oxidation of $1 \%$ tetramethyl-p-phenylenediamine on filter paper. Tests for utilization of various organic substrates as sole carbon and energy sources were performed as described previously (22). Most of the substrates were tested at a concentration of $1 \%$ 
(wt/vol); the exceptions were glycerol $(0.1 \%$, wt/vol), pyridine $(0.01 \%$, wt/vol), and phenol $(0.01 \%, w t / v o l)$. Other phenotypic tests were performed with the API 20NE system (BioMerieux, Marcy-l'Etoile, France).

Isolation of DNA. Chromosomal DNA was isolated and purified by the method described previously (33).

Determination of $\mathbf{G}+\mathbf{C}$ content. The guanine-plus-cytosine $(\mathrm{G}+\mathrm{C})$ content was determined by the method of Tamaoka and Komagata (25). DNA was hydrolyzed and dephosphorylated, and the resultant nucleosides were analyzed by isocratic reverse-phase high-performance liquid chromatography (HPLC) by using an instrument equipped with a Novapak $\mathrm{C}_{18}$ column (Millipore, Waters, Bedford, Mass.)

Analysis of isoprenoid quinones. Menaquinones were extracted and purified as described by Komagata and Suzuki (7) except for the use of an alternative solvent system for thin-layer chromatography; this solvent system was petroleum ether-diethyl ether $(85: 15, \mathrm{vol} / \mathrm{vol})$. The purified menaquinones were dissolved in acetone and separated by isocratic reverse-phase HPLC by using methanolisopropyl alcohol $(50: 50, \mathrm{vol} / \mathrm{vol})$ as the eluting solvent.

Fatty acid methyl ester analysis. Bacterial cultures were harvested from nutrient agar plates for total fatty acid analysis. Fatty acids were extracted and analyzed by using the instructions of the Microbial Identification System (MIDI; Microbial ID, Inc., Newark, Del.).

Cell wall analysis. The diamino acid of the peptidoglycan was determined by the method described previously (7). The cell wall sugar analysis was performed at the whole-cell level by the method described previously (7).

16S rDNA sequence analysis. Two primers described previously (20), primers 9F (5'-GAGTTTGATCCTGGCTCAG-3'; positions 9 to 27 [Escherichia coli $16 \mathrm{~S}$ rRNA numbering]) and 1542R (5'-AGAAAGGAGGTGATCCAGCC-3'; positions 1542 to 1525 [E. coli $16 \mathrm{~S}$ rRNA numbering]), were used for amplification of the $16 \mathrm{~S}$ rRNA gene. The $5^{\prime}$ ends of the two primers were phosphorylated by using T4 polynucleotide kinase (New England Biolabs, Inc., Beverly, Mass.) according to the instructions included with a Strandase ssDNA preparation kit (Novagen, Inc., Madison, Wis.). The 16S rRNA gene was amplified as described previously (34) by using phosphorylated primer $9 \mathrm{~F}$ plus nonphosphorylated primer $1542 \mathrm{R}$ and phosphorylated primer $1542 \mathrm{R}$ plus nonphosphorylated primer 9F. The PCR products were precipitated with $1 \mu \mathrm{l}$ of $1 \%$ (wt/vol) glycogen, $9 \mu$ of $3 \mathrm{M}$ sodium acetate $(\mathrm{pH} \mathrm{5.2)}$, and $70 \mu \mathrm{l}$ of isopropanol and were resuspended in $10 \mu$ l of distilled water.

The strands containing phosphorylated primer from PCR products were selectively digested by using $\lambda$ exonuclease according to the instructions included with the Strandase ssDNA preparation kit (Novagen, Inc.). The single-stranded DNA templates produced were directly used for the sequencing reaction. Sequencing was performed as described previously (6) by using $\alpha-{ }^{35} \mathrm{~S}$-labelled dATP and a DNA sequencing kit (U.S. Biochemicals, Cleveland, Ohio). The sequencing primers were derived from conserved regions of the 16S rRNA gene.

Phylogenetic analysis. The $16 \mathrm{~S}$ rDNA sequence of strain $\mathrm{OS}^{\mathrm{T}}$ was aligned with the $16 \mathrm{~S}$ rRNA and rDNA sequences of representatives of the genus $\mathrm{No}$ cardioides and some other actinomycete taxa by using CLUSTAL W software (28). Gaps at the $5^{\prime}$ end and $3^{\prime}$ end of the alignment were omitted from further analysis. Therefore, the region compared and used to calculate sequence similarity values and evolutionary distances corresponds to the region between positions 61 and 1484 (E. coli 16S rRNA numbering). Reference sequences were obtained from the EMBL and GenBank databases, where the nucleotide sequences are available under the following accession numbers: X53211 (N. albus), X53214 (N. jensenii), X53212 (N. luteus), X69973 ( $N$. plantarum), M37200 (Aeromicrobium erythreum), X53189 (Aeromicrobium fastidiosum), M23411 (Arthrobacter globiformis), M38242 (Micrococcus luteus), X72377 (Sporichthya polymorpha), M76388 (Streptomyces griseus subsp. griseus), Y00484 ("Streptomyces lividans"), and X53215 (T. tumescens). The 16S rRNA sequence of N. simplex was obtained from the study of Collins et al. (3). 16S rDNA similarity values were calculated from the alignment, and evolutionary distances were calculated by using the Kimura two-parameter correction with the CLUSTAL W package (28). A phylogenetic tree was constructed by using the neighbor-joining method (16) on the basis of distance matrix data.

Nucleotide sequence accession number. The 16S rRNA gene sequence of strain $\mathrm{OS} 4^{\mathrm{T}}$ has been deposited in the GenBank database under accession no. U61298.

\section{RESULTS}

Morphological and physiological characteristics. Strain $\mathrm{OS} 4^{\mathrm{T}}$ is an aerobic, non-spore-forming, motile, gram-positive organism that is gram variable in old cultures. The colonies are smooth, round, raised, and cream colored on nutrient agar (Difco). They are approximately 1.0 to $1.5 \mathrm{~mm}$ in diameter after 5 days at $35^{\circ} \mathrm{C}$ on nutrient agar (Difco). This strain grew slowly on complex media such as Luria-Bertani medium and nutrient agar (Difco) but grew well on minimal salts medium supplemented with $0.05 \%$ (wt/vol) yeast extract and $0.05 \%$ (wt/vol) tryptone; a developed vegetative mycelium was not formed. Single cells are rod shaped in the exponential phase of growth and bear a single polar flagellum (Fig. 1). The cells are 0.5 to $0.6 \mu \mathrm{m}$ in diameter and 1.2 to $1.6 \mu \mathrm{m}$ long. The cells show rod-to-coccus morphogenesis from the early exponential phase to the stationary phase and produce $\mathrm{V}$-forms, indicating that postfission movement occurs during vegetative growth.

Strain $0 S 4^{\mathrm{T}}$ had catalase activity but no oxidase activity. Acid was not produced from glucose. Nitrate was reduced to nitrite. Strain $\mathrm{OS} 4^{\mathrm{T}}$ grew at $\mathrm{pH} 5$ and 9 and at 20 and $40^{\circ} \mathrm{C}$. The optimal temperature and $\mathrm{pH}$ were $35^{\circ} \mathrm{C}$ and 8.0 , respectively.

Chemotaxonomic characteristics and DNA base composition. Strain OS4 ${ }^{\mathrm{T}}$ has the LL form of diaminopimelic acid as the diamino acid in its cell wall, indicating that the wall chemotype is type I. The major sugar found in the cell wall is galactose, and small amounts of glucose and ribose are also present.

The major menaquinone of strain $\mathrm{OS} 4^{\mathrm{T}}$ is a tetrahydrogenated menaquinone with eight isoprenoid units $\left[\mathrm{MK}-8\left(\mathrm{H}_{4}\right)\right]$, and in addition, minor amounts of $\mathrm{MK}-7\left(\mathrm{H}_{4}\right)$ and $\mathrm{MK}-8\left(\mathrm{H}_{2}\right)$ are present.

The major cellular fatty acids are iso- $\mathrm{C}_{16: 0}$ and 10 -methylbranched fatty acids which are characteristic of the genus $\mathrm{No}$ cardioides. Strain $\mathrm{OS} 4^{\mathrm{T}}$ also has significant amounts of anteiso$\mathrm{C}_{17: 0}$, which is not found in other Nocardioides species (Table 1).

The genomic DNA G+C content of strain $\mathrm{OS} 4^{\mathrm{T}}$ is 72.5 mol\%, indicating that this strain belongs to the high-G $+\mathrm{C}$ content group of gram-positive bacteria.

Phylogenetic analysis. The nearly complete $16 \mathrm{~S}$ rRNA gene of OS4 $4^{\mathrm{T}}$ was amplified by PCR by using universal primers described previously (20) and was directly sequenced. The sequence of the $16 \mathrm{~S}$ rRNA gene determined was $1,482 \mathrm{bp}$ long and corresponded to the region between positions 28 and 1524 by comparison with the $16 \mathrm{~S}$ rDNA of $E$. coli. The $16 \mathrm{~S}$ rDNA sequence of strain $\mathrm{OS}^{\mathrm{T}}$ was compared with the 16S rDNA sequences of Nocardioides species and some other actinomycete taxa, and the nucleotide similarity values and evolutionary distances were calculated from a 1,430-nucleotide region. Figure 2 shows a phylogenetic tree constructed by the neighbor-joining method on the basis of the evolutionary distance matrix. Isolate $\mathrm{OS} 4^{\mathrm{T}}$ forms a distinct lineage within the evolutionary radiation enclosed by the genus Nocardioides.

\section{DISCUSSION}

The results of chemotaxonomic analyses and phylogenetic inferences based on $16 \mathrm{~S}$ rDNA sequences indicate that strain $\mathrm{OS} 4^{\mathrm{T}}$ belongs to the genus Nocardioides. It is a fact that morphological traits cause confusion when workers attempt to assign a new isolate to the genus Nocardioides. Previous inclusion of Pimelobacter species in the genus Nocardioides rendered the genus morphologically heterogeneous (24). N. albus (13) and $N$. luteus (14) produce a well-developed mycelium, whereas $N$. jensenii (3), N. plantarum (4), and N. simplex (12) form neither substrate mycelium nor primary mycelium. Consequently, morphological traits, as well as physiological properties, are not sufficient for definitive identification of strain OS4 ${ }^{\mathrm{T}}$. Additionally, chemotaxonomic and phylogenetic analyses are necessary for exact identification of strain $\mathrm{OS} 4^{\mathrm{T}}$.

Our cell wall analysis showed that strain $\mathrm{OS} 4^{\mathrm{T}}$ contained LL-diaminopimelic acid, which is the diagnostic diamino acid of wall chemotype I. Representative taxa containing LL-diaminopimelic acid in the cell wall include the genera Intrasporangium, Kineosporia, Nocardioides, Sporichthya, Streptomyces, and Terrabacter (29), as well as the genera Aeromicrobium (10), Luteococcus (26), Microlunatus (11), Propionibacterium (1), 


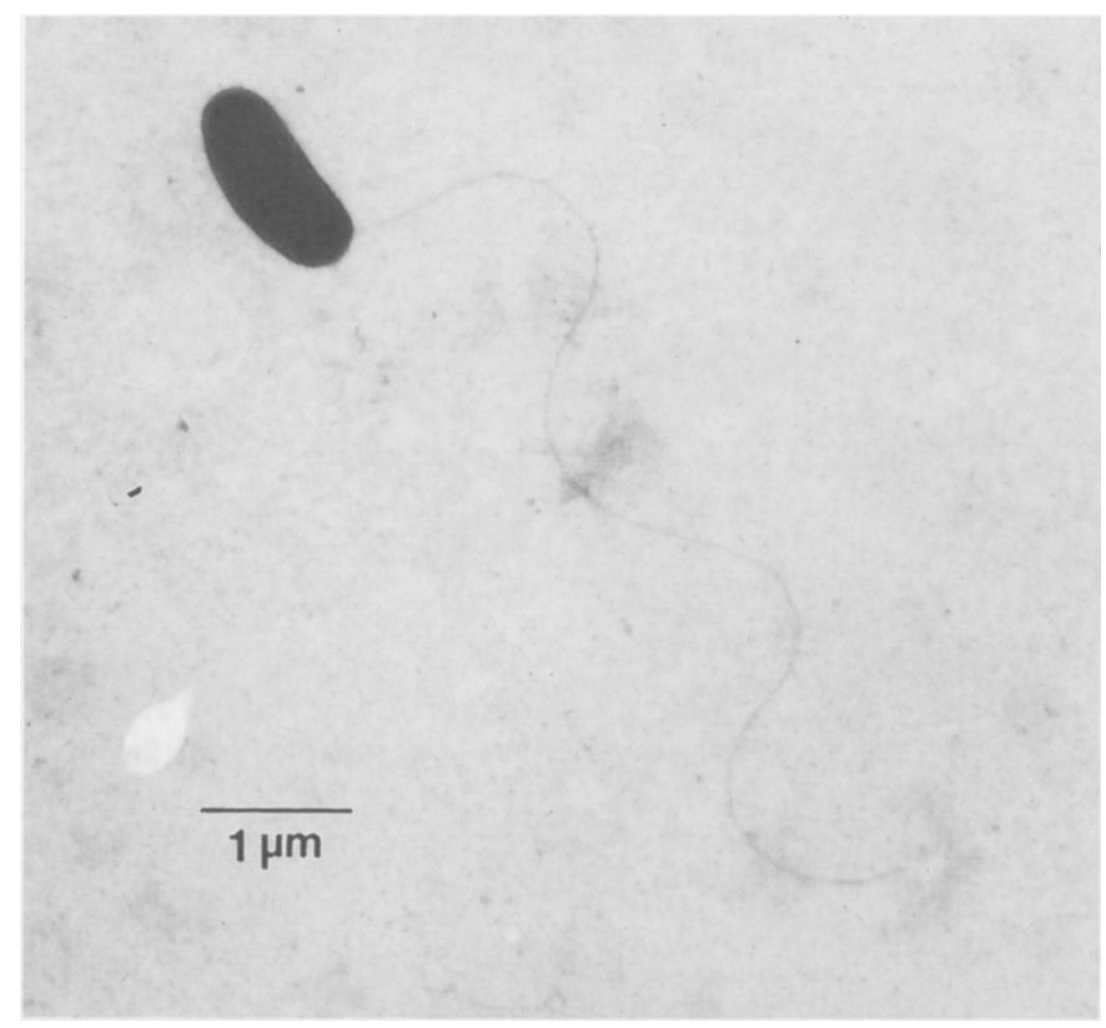

FIG. 1. Transmission electron micrograph of strain $\mathrm{OS}^{\mathrm{T}}$ from the exponential growth phase.

and Propionifelax (32). The menaquinone type is important in distinguishing the genus Nocardioides from other genera containing LL-diaminopimelic acid in the cell wall. Among the genera containing LL-diaminopimelic acid in the cell wall, only the genera Nocardioides and Terrabacter contain a tetrahydrogenated menaquinone with eight isoprenoid units $\left[\mathrm{MK}-8\left(\mathrm{H}_{4}\right)\right]$ $(12,27)$. Although the genus Terrabacter has the same menaquinone type as the genus Nocardioides, it has been found to be phylogenetically distantly related to the genus Nocardioides (3). Previously, Nocardioides species have been shown to have MK-8 $\left(\mathrm{H}_{4}\right)$ or MK-9 $\left(\mathrm{H}_{4}\right)$ as their predominant menaquinone. However, N. fastidiosa, which has $\mathrm{MK}-9\left(\mathrm{H}_{4}\right)$ as its predominant menaquinone, has recently been transferred to the genus Aeromicrobium as Aeromicrobium fastidiosum (27). Although the genus Aeromicrobium is phylogenetically related to the genus Nocardioides (10), it possesses a tetrahydrogenated menaquinone with nine isoprenoid units $\left[\mathrm{MK}-9\left(\mathrm{H}_{4}\right)\right]$ as its predominant menaquinone $(10,27)$.

Complex fatty acid types have been found in some actinomycetes, including the genus Nocardioides. Fatty acid profiles also show that strain $\mathrm{OS}^{\mathrm{T}}$ is a member of the genus Nocardioides. The major fatty acids of strain $\mathrm{OS} 4^{\mathrm{T}}$ are iso- $\mathrm{C}_{16: 0}$ and 10-methyl branched acids (Table 1). This is consistent with the fatty acid patterns of other Nocardioides species but different from the fatty acid patterns of Aeromicrobium species $(10,27)$. The genus Aeromicrobium has significant amounts of $\mathrm{C}_{16: 0}$, $\mathrm{C}_{18: 1}$, and 10-methyl- $\mathrm{C}_{18: 0}$ as its major fatty acids (10). Therefore, the diagnostic fatty acids for distinction between the genera Nocardioides and Aeromicrobium are iso- $\mathrm{C}_{16: 0}, \mathrm{C}_{16: 0}, \mathrm{C}_{18: 1}$, and 10-methyl- $\mathrm{C}_{\text {18:0 }}$ (Table 1).

Phylogenetic analysis based on $16 \mathrm{~S}$ rDNA sequences is currently one of the most effective methods for estimating relationships between bacteria (21). A comparison of the $16 \mathrm{~S}$
rDNA sequence of strain OS $4^{\mathrm{T}}$ with the $16 \mathrm{~S}$ rDNA sequences of previously described Nocardioides species and other actinomycete taxa showed that strain OS4 ${ }^{\mathrm{T}}$ belongs to the genus Nocardioides (Fig. 2). This phylogenetic inference is consistent with results obtained in the chemotaxonomic analyses. Strain $\mathrm{OS} 4{ }^{\mathrm{T}}$ showed $16 \mathrm{~S}$ rRNA and $16 \mathrm{~S}$ rDNA similarity values of $94.5 \% \pm 0.7 \%$ for a 1,430 -nucleotide region with previously described Nocardioides species. A threshold value for $16 \mathrm{~S}$ rRNA and 16S rDNA similarity values for species definition has been recognized (19). The phylogenetic definition of a species states that "strains with approximately $70 \%$ or greater DNA-DNA relatedness" are members of the same species (30, 31). According to Stackebrandt and Goebel (19), "organisms that have less than $97 \%$ sequence homology will not reassociate to more than $60 \%$, no matter which hybridization method is applied." Therefore, strain OS $4^{\mathrm{T}}$ should be given status as a member of a new species in the genus Nocardioides on the basis of the 16S rDNA sequence analysis. The tree based on 16S rDNA sequences shows the phylogenetic position of strain $\mathrm{OS}^{\mathrm{T}}$ as a new species in the genus Nocardioides (Fig. 2).

On the basis of the data described above, we propose a new species, Nocardioides pyridinolyticus, for strain OS4 ${ }^{\mathrm{T}}$. The properties of the species are summarized below.

Description of Nocardioides pyridinolyticus sp. nov. Nocardioides pyridinolyticus (py.ri.di.no.ly'ti.cus. M. L. n. pyridin, pyridine; M. L. adj. lyticus, dissolving; M. L. adj. pyridinolyticus, pyridine dissolving). Cells are aerobic, non-spore-forming rods that are 0.5 to $0.6 \mu \mathrm{m}$ wide and 1.2 to $1.6 \mu \mathrm{m}$ long in the exponential phase of growth. Cells exhibit rod-to-coccus morphogenesis from the early exponential phase to the stationary phase. Gram positive and gram variable in old cultures. Motile by means of a single polar flagellum. Colonies are smooth, 
TABLE 1. Cellular fatty acid profiles of $N$. pyridinolyticus $\mathrm{OS} 4^{\mathrm{T}}$, representatives of the genera Nocardioides and Aeromicrobium, and T. tumescens

\begin{tabular}{|c|c|c|c|c|c|c|c|c|}
\hline \multirow[b]{2}{*}{ Fatty acid } & \multicolumn{8}{|c|}{$\%$ in: } \\
\hline & 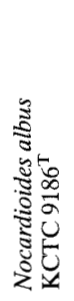 & 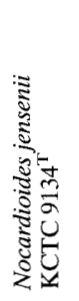 & 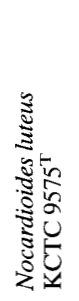 & 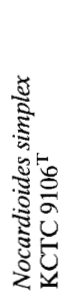 & 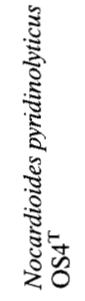 & 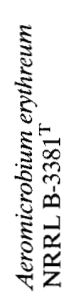 & 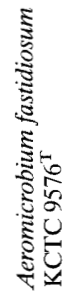 & 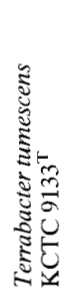 \\
\hline \multicolumn{9}{|l|}{ Saturated fatty acids } \\
\hline $\mathrm{C}_{14: 0}$ & & & & & & 0.7 & 0.6 & 7.0 \\
\hline $\mathrm{C}_{15: 0}$ & 0.7 & 0.3 & & & 0.4 & 1.7 & 1.0 & 4.9 \\
\hline $\mathrm{C}_{16: 0}$ & 0.7 & 1.3 & 0.6 & 1.1 & 1.2 & 20.0 & 10.1 & 12.5 \\
\hline $\mathrm{C}_{17: 0}$ & 1.5 & 2.7 & 0.5 & & 1.2 & 2.4 & 2.1 & 5.3 \\
\hline $\mathrm{C}_{18: 0}$ & & 2.0 & & 1.3 & 1.0 & 6.1 & 9.7 & 7.8 \\
\hline $\mathrm{C}_{19: 0}$ & & & & & & & & 1.6 \\
\hline \multicolumn{9}{|l|}{ Unsaturated fatty acids } \\
\hline $\mathrm{C}_{15: 1} \omega 6 \mathrm{c}$ & & 0.3 & & & & & & 0.9 \\
\hline $\mathrm{C}_{16: 1} \omega 9 \mathrm{c}$ & & & & & & 0.8 & 1.4 & 0.3 \\
\hline$C_{17: 1}^{10.1} \omega 6 \mathrm{c}$ & 15.6 & 5.2 & 15.9 & 13.1 & & 0.6 & & \\
\hline $\mathrm{C}_{17: 1} \omega 8 \mathrm{c}$ & 2.8 & 3.4 & 1.1 & 2.3 & 1.7 & 0.8 & & 5.8 \\
\hline $\mathrm{C}_{17: 1} \omega 9 \mathrm{c}$ & & & & & & & 0.9 & \\
\hline $\mathrm{C}_{18: 1} \omega 9 \mathrm{c}$ & & 3.3 & & 7.3 & 2.0 & 25.6 & 25.1 & 13.9 \\
\hline $\mathrm{C}_{19: 1}$ iso I & & & & 1.6 & & & & \\
\hline \multicolumn{9}{|l|}{ Branched fatty acids } \\
\hline iso- $\mathrm{C}_{14: 0}$ & 2.2 & 1.1 & 0.7 & 1.6 & 0.5 & & & 4.3 \\
\hline iso- $C_{15: 0}$ & 3.1 & 3.7 & 3.7 & 1.5 & 5.1 & & & 8.3 \\
\hline anteiso- $\mathrm{C}_{15: 0}$ & & & & & 1.4 & & & 2.1 \\
\hline iso- $\mathrm{C}_{14: 0} 3-\mathrm{OH}$ & & & 0.6 & & & & & \\
\hline iso- $\mathrm{C}_{16: 1} \mathrm{H}$ & 1.1 & 14.0 & 2.1 & 5.4 & 4.2 & & & 1.0 \\
\hline iso- $\mathrm{C}_{16: 0}$ & 53.6 & 45.5 & 49.1 & 33.7 & 47.3 & 1.4 & & 5.6 \\
\hline iso- $\mathrm{C}_{17: 0}$ & 1.3 & 1.7 & 1.0 & 2.2 & 1.7 & & & \\
\hline iso- $\mathrm{C}_{17: 1} \omega 9 \mathrm{c}$ & & & & & & 0.4 & 0.7 & \\
\hline anteiso- $\mathrm{C}_{17: 1} \omega 9 \mathrm{c}$ & & & & & 2.12 & & & \\
\hline anteiso- $\mathrm{C}_{17: 0}$ & 0.7 & 0.7 & 1.4 & 0.5 & 14.2 & & & 1.1 \\
\hline iso- $\mathrm{C}_{18: 0}$ & 0.9 & 2.7 & & 0.9 & 0.5 & 0.5 & & \\
\hline \multicolumn{9}{|l|}{ 10-Methyl-fatty acids } \\
\hline $\mathrm{C}_{16: 0}$ & 1.5 & 2.5 & 5.0 & 4.0 & 5.0 & & & 2.8 \\
\hline $\mathrm{C}_{17: 0}$ & 12.2 & 5.4 & 15.0 & 5.4 & 5.5 & 0.3 & & 1.2 \\
\hline $\mathrm{C}_{18: 0}$ & 2.3 & 2.4 & 2.9 & 9.3 & 3.4 & 24.2 & 32.9 & 1.0 \\
\hline \multicolumn{9}{|l|}{ Hydroxy fatty acids } \\
\hline $\mathrm{C}_{15.0} 2-\mathrm{OH}$ & & & & & & 0.6 & 0.6 & \\
\hline $\mathrm{C}_{16: 0} 2-\mathrm{OH}$ & & & & 0.7 & & 11.3 & 8.9 & \\
\hline $\mathrm{C}_{17: 0} 2-\mathrm{OH}$ & & & & & & 0.9 & 1.5 & \\
\hline $\mathrm{C}_{18: 0} 2-\mathrm{OH}$ & & & & & & 1.1 & 3.7 & \\
\hline \multicolumn{9}{|l|}{ Summed features ${ }^{a}$} \\
\hline Summed feature 4 & & 1.2 & & 5.1 & 0.8 & & 0.9 & 8.1 \\
\hline Summed feature 6 & & & & 0.7 & & & & 1.7 \\
\hline Summed feature 7 & & & & 2.4 & & & & 1.0 \\
\hline Summed feature 8 & & & & & 0.5 & & & 1.9 \\
\hline
\end{tabular}

${ }^{a}$ Summed features represent groups of two or three fatty acids which could not be separated by gas-liquid chromatography with the MIDI system. Summed feature 4 contained one or more of the following fatty acids: iso- $\mathrm{C}_{1500} 2-\mathrm{OH}$ and $\mathrm{C}_{16: 1} \omega 7 \mathrm{c}$. Summed feature 6 contained one or more of the following fatty acids: anteiso- $\mathrm{C}_{18 \cdot 0}$ and $C_{18: 2} \omega 6,9 \mathrm{c}$. Summed feature 7 contained one or more of the following fatty acids: $C_{18: 1} \omega 7 \mathrm{c}, C_{18: 1} \omega 9 \mathrm{t}$, and $C_{18: 1} \omega 12 \mathrm{t}$. Summed feature 8 contained one or more of the following fatty acids: unknown 18.756 and $C_{19: 1} \omega 11 \mathrm{c}$.

round, and cream colored on nutrient agar. They are approximately 1.0 to $1.5 \mathrm{~mm}$ in diameter after 5 days at $35^{\circ} \mathrm{C}$. Neither substrate mycelium nor primary mycelium is formed. Strain $\mathrm{OS} 4^{\mathrm{T}}$ grows at $\mathrm{pH} 5$ and 9 and at 20 and $40^{\circ} \mathrm{C}$. The optimal growth temperature and $\mathrm{pH}$ for strain $\mathrm{OS} 4^{\mathrm{T}}$ are $35^{\circ} \mathrm{C}$ and 8.0 , respectively. Catalase positive. Oxidase negative. Acid is not produced from glucose. Esculin and gelatin are hydrolyzed. Indole is not produced. Nitrate is reduced to nitrite. D-Glucose, D-ribose, D-xylose, D-fructose, D-galactose, D-mannose, L-rhamnose, D-cellobiose, lactose, maltose, sucrose, D-treha- lose, myo-inositol, D-mannitol, pyridine, and phenol are utilized as sole carbon and energy sources for growth. L-Arabinose, D-melibiose, D-raffinose, adonitol, D-sorbitol, inulin, and glycerol are not utilized.

The cell wall peptidoglycan contains LL-diaminopimelic acid as the diamino acid (wall chemotype I). The predominant menaquinone is MK-8 $\left(\mathrm{H}_{4}\right)$, and minor amounts of $\mathrm{MK}-7\left(\mathrm{H}_{4}\right)$ and MK- $8\left(\mathrm{H}_{2}\right)$ are also present. The cellular fatty acids are composed of saturated, unsaturated, iso-, anteiso- and 10methyl-branched types, and the major fatty acids are iso- $\mathrm{C}_{16: 0}$ 


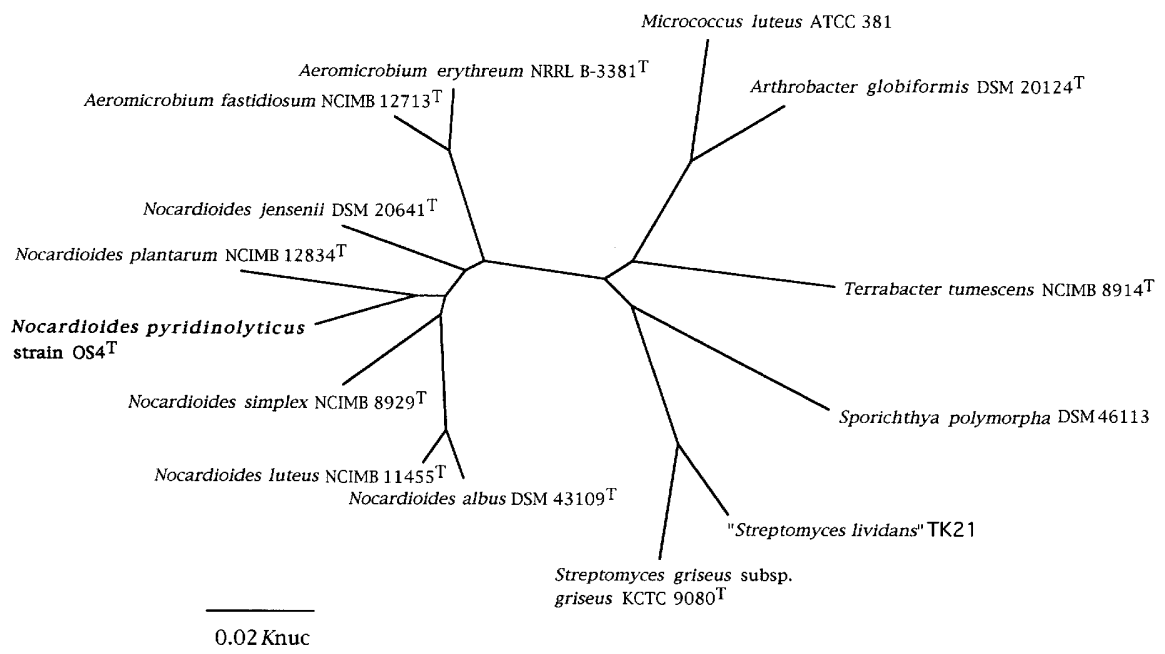
taxa.

FIG. 2. Unrooted phylogenetic tree showing the positions of $N$. pyridinolyticus $04^{\mathrm{T}}$, other representatives of the genus Nocardioides, and some other actinomycete

and 10-methyl-branched acids. The $\mathrm{G}+\mathrm{C}$ content of the DNA is $72.5 \mathrm{~mol} \%$ (as determined by HPLC). Isolated from the oxic zone of an oil shale column. The type strain is OS4, which has been deposited in the Korean Collection for Type Cultures as KCTC 0074BP.

\section{ACKNOWLEDGMENTS}

This work was supported by grant HS1331 from the Ministry of Science and Technology of the Republic of Korea.

We are grateful to Yong Kook Shin and Sam-Bong Kim for helpful discussions and to J. L. Swezey of the ARS Patent Culture Collection, Microbial Properties Research, for providing Aeromicrobium erythreum NRRL B-3381.

\section{REFERENCES}

1. Charfreitag, O., and E. Stackebrandt. 1989. Intra- and intergeneric relationships of the genus Propionibacterium. J. Gen. Microbiol, 135:2065-2070.

2. Collins, M. D., and E. Stackebrandt. 1989. Molecular taxonomic studies on some LL-diaminopimelic acid-containing coryneforms from herbage: description of Nocardioides fastidiosa sp. nov. FEMS Microbiol. Lett. 57:289-294.

3. Collins, M. D. M. Dorsch, and E. Stackebrandt 1989. Transfer of Pimelobacter tumescens to Terrabacter gen. nov. as Terrabacter tumescens comb. nov. and of Pimelobacter jensenii to Nocardioides as Nocardioides jensenii comb. nov. Int. J. Syst. Bacteriol. 39:1-6.

4. Collins, M. D., S. Cockcroft, and S. Wallbanks. 1994. Phylogenetic analysis of a new LL-diaminopimelic acid-containing coryneform bacterium from herbage, Nocardioides plantarum sp. nov. Int. J. Syst. Bacteriol. 44:523-526.

5. Jori, A., D. Calamari, E. Cattabeni, A. D. Domenico, C. L. Galli, E. Galli, and V. Silano. 1983. Ecotoxicological profile of pyridine. Ecotoxicol. Environ. Safety $7: 251-275$

6. Kim, S.-B., J.-H. Yoon, H. Kim, S. T. Lee, Y.-H. Park, and M. Goodfellow. 1995. A phylogenetic analysis of the genus Saccharomonospora conducted with 16S rRNA gene sequences. Int. J. Syst. Bacteriol. 45:351-356.

7. Komagata, K., and K. Suzuki. 1987. Lipids and cell-wall analysis in bacterial systematics. Methods Microbiol. 19:161-203.

8. Lee, S.-T., S.-K. Rhee, and G. M. Lee. 1994. Biodegradation of pyridine by freely suspended and immobilized Pimelobacter sp. Appl. Microbiol. Biotechnol. 41:652-657.

9. Leenheer, J. A., and H. A. Stuber. 1981. Migration through soil of organic solutes in an oil-shale process water. Environ. Sci. Technol. 15:14671475 .

10. Miller, E. S., C. R. Woese, and S. Brenner. 1991. Description of the erythromycin-producing bacterium Arthrobacter sp. strain NRRL B-3381 as Aeromicrobium erythreum gen. nov., sp. nov. Int. J. Syst. Bacteriol. 41:363368 .

11. Nakamura, K., A. Hiraishi, Y. Yoshimi, M. Kawaharasaki, K. Masuda, and Y. Kamagata. 1995. Microlunatus phosphovorus gen. nov., sp. nov., a new gram-positive polyphosphate-accumulating bacterium isolated from acti- vated sludge. Int. J. Syst. Bacteriol. 45:17-22.

12. O'Donnell, A. G., M. Goodfellow, and D. E. Minnikin. 1982. Lipids in the classification of Nocardioides: reclassification of Arthrobacter simplex (Jensen) Lochhead in the genus Nocardioides (Prauser) emend. O'Donnell et al. as Nocardioides simplex comb. nov. Arch. Microbiol. 133:323-329.

13. Prauser, H. 1976. Nocardioides, a new genus of the order Actinomycetales. Int. J. Syst. Bacteriol. 26:58-65.

14. Prauser, H. 1984. Nocardioides luteus spec. nov. Z. Allg. Mikrobiol. 24:647648

15. Rhee, S.-K., G. M. Lee, Y. B. Kim, and S.-T. Lee. 1996. Effects of pyridine on the fatty acid composition of Pimelobacter sp. FEMS Microbiol. Lett. 141: 139-143.

16. Saitou, N., and M. Nei. 1987. The neighbor-joining method: a new method for reconstructing phylogenetic trees. Mol. Biol. Evol. 4:406-425.

17. Sims, G. K., and L. E. Sommers. 1985. Degradation of pyridine derivatives in soil. J. Environ. Qual. 14:580-584.

18. Skerman, V. B. D. 1967. A guide to the identification of the genera of bacteria, 2nd ed. The Williams \& Wilkins Co., Baltimore, Md.

19. Stackebrandt, E., and B. M. Goebel. 1994. Taxonomic note: a place for DNA-DNA reassociation and 16S rRNA sequence analysis in the present species definition in bacteriology. Int. J. Syst. Bacteriol. 44:846-849.

20. Stackebrandt, E., and W. Liesack. 1993. Nucleic acids and classification, p. 152-189. In M. Goodfellow and A. G. O'Donnell (ed.), Handbook of new bacterial systematics. Academic Press, London, United Kingdom.

21. Stackebrandt, E., F. A. Rainey, and N. L. Ward-Rainey. 1997. Proposal for a new hierarchic classification system, Actinobacteria classis nov. Int. J. Syst. Bacteriol. 47:479-491.

22. Stevenson, I. L. 1967. Utilization of aromatic hydrocarbons by Arthrobacter spp. Can. J. Microbiol. 13:205-211

23. Stuermer, D. H., D. J. Ng, and C. J. Morris. 1982. Organic contaminants in groundwater near an underground coal gasification site in northeastern Wyoming. Environ. Sci. Technol. 16:582-587.

24. Suzuki, K., and K. Komagata. 1983. Pimelobacter gen. nov., a new genus of coryneform bacteria with LL-diaminopimelic acid in the cell wall. J. Gen. Appl. Microbiol. 29:59-71.

25. Tamaoka, J., and K. Komagata. 1984. Determination of DNA base composition by reverse-phase high-performance liquid chromatography. FEMS Microbiol. Lett. 25:125-128.

26. Tamura, T., M. Takeuchi, and A. Yokota. 1994. Luteococcus japonicus gen. nov., a new gram-positive coccus with $\mathrm{LL}$-diaminopimelic acid in the cell wall. Int. J. Syst. Bacteriol. 44:348-356.

27. Tamura, T., and A. Yokota. 1994. Transfer of Nocardioides fastidiosa Collins and Stackebrandt 1989 to the genus Aeromicrobium as Aeromicrobium fas. tidiosum comb. nov. Int. J. Syst. Bacteriol. 44:608-611.

28. Thompson, J. D., D. G. Higgins, and T. J. Gibson. 1994. CLUSTAL W: improving the sensitivity of progressive multiple sequence alignment through sequence weighting, position specific gap penalties and weight matrix choice. Nucleic Acids Res. 22:4673-4680.

29. Uchida, K., and A. Seino. 1997. Intra- and intergeneric relationships of various actinomycete strains based on the acyl types of the muramyl residue in cell wall peptidoglycans examined in a glycolate test. Int. J. Syst. Bacteriol. 47:182-190. 
30. Wayne, L. G., D. J. Brenner, R. R. Colwell, P. A. D. Grimont, O. Kandler, M. I. Krichevsky, L. H. Moore, W. E. C. Moore, R. G. E. Murray, E. Stackebrandt, M. P. Starr, and H. G. Trüper. 1987. Report of the Ad Hoc Committee on Reconciliation of Approaches to Bacterial Systematics. Int. J. Syst. Bacteriol. 37:463-464.

31. Wiese, B. G., W. Strohmar, F. A. Rainey, and H. Diekmann. 1996. Lactobacillus panis sp. nov., from sourdough with a long fermentation period. Int. J. Syst. Bacteriol. 46:449-453.

32. Yokota, A., T. Tamura, M. Takeuchi, N. Weiss, and E. Stackebrandt. 1994. Transfer of Propionibacterium innocuum Pitcher and Collins 1991 to
Propioniferax gen. nov. as Propionifelax innocua comb. nov. Int. J. Syst. Bacteriol. 44:579-582.

33. Yoon, J.-H., H. Kim, S.-B. Kim, H.-J. Kim, W. Y. Kim, S. T. Lee, M. Goodfellow, and Y.-H. Park. 1996. Identification of Saccharomonospora strains by the use of genomic DNA fragments and rRNA gene probes. Int. J. Syst. Bacteriol. 46:502-505.

34. Yoon, J.-H., S. T. Lee, S.-B. Kim, W. Y. Kim, M. Goodfellow, and Y.-H. Park. 1997. Restriction fragment length polymorphism analysis of PCR-amplified $16 \mathrm{~S}$ ribosomal DNA for rapid identification of Saccharomonospora strains. Int. J. Syst. Bacteriol. 47:111-114. 